\title{
Crossflow microfiltration in the dairy industry: state-of-the-art
}

\author{
U Merin 1, G Daufin 2* \\ 1 Agricultural Research Organization, Dairy Science Laboratory, The Volcani Center, \\ PO Box 6, Bet Dagan 50250, Israel; \\ 2 INRA, Laboratoire de Recherches de Technologie Laitière, \\ 65 rue de St Brieuc, 35042 Rennes Cedex, France
}

(Received 26 February 1990; accepted 13 May 1990)

\begin{abstract}
Summary - Crossflow microfiltration is a relatively new membrane process which was introduced to the dairy industry in the last decade. Its present applications to dairy feed streams, the problems associated with its operation and its cleaning are reviewed.
\end{abstract}

microfiltration / milk / whey / fouling / cleaning

Résumé - Microfiltration tangentielle dans l'industrie laitière: synthèse bibliographique. La microfiltration tangentielle est un procédé de séparation sur membrane qui fut introduit dans l'industrie laitière au cours de la dernière décennie. L'application de la microfiltration à la clarification et à la délipidation du lactosérum est décrite. Les performances de la microfiltration dépendent de la vitesse d'écoulement tangentiel et de la nature de la pompe de recirculation du rétentat. Dans le cas du lait écrémé, l'épuration bactérienne est un procédé prometteur (haut flux; forte réduction bactérienne; faible rétention de caséine) qui met en œuvre le système de pression transmembranaire constant. La séparation du phosphocaséinate et l'écrémage paraissent réalisables par microfiltration, mais nécessitent des études approfondies. Les problèmes liés à la sélectivité du procédé et des paramètres qui l'influencent, l'encrassement et le nettoyage des membranes sont également passés en revue.

microfiltration / lait / lactosérum / encrassement / nettoyage

\section{INTRODUCTION}

Microfiltration (MF) is one of the first filtration processes, commercially developed by Sartorius-Werke in Germany in 1929. In the beginning, it was only used for research but, during World War II, it was adapted for bacteriological analysis of water supplies. Until 1963, microfilters were predominantly nitrocellulose, or a mixture of cellulose esters. The need for improved chemical resistance and heat stability of the membranes prompted investigations of new materials and methods of fabrication (Lonsdale, 1982; Cheryan, 1986; Porter, 1986).

The main uses of microfilters are water purification and sterilization and microbio-

\footnotetext{
* Correspondence and reprints
} 
logical and related analytical applications, such as the direct epifluorescent filter technique (DEFT) (Pettipher et al, 1980). In the food industry, they are mainly used for water and beverage sterilization. Industrial units are stack-plate filters and cartridges (Cheryan, 1986; Porter, 1986), serving as filters, all of which are operating as depth or dead-ended filters (Bertera et al, 1984).

Tangential or cross flow microfiltration (CFMF) is a pressure driven membrane process, similar to ultrafiltration (UF). MF could be used for coarse filtration of particulates and bacteria as well as to fine separation of soluble protein, small molecular solutes and water. MF processes usually operate at pressures of $0.1-8$ bars, which at the lower range are somewhat lower than that of UF. This operational difference becomes important in situations in which the MF membrane is susceptible to fouling and to the formation of a boundary layer. by gelatinous material, the hydrodynamic resistance of which may be increased by high operating pressures. These 2 flux depressing phenomena are the major difficulties to be overcome in applying MF to any feed stream. Concentration polarization and fouling induce the formation of a dynamic membrane (Tanny, 1978; Belfort, 1985), due to particulates blocking the pores and adsorbed layers, which quickly becomes the major hydrodynamic resistance to flow and decreases membrane performance to such a degree that it prevents the extended use of MF. This membrane performance consists of 2 major antagonistic phenomena. MF could only operate economically at high fluxes for a long time. Fulfilling this first goal leads to higher retention of large molecules which finally results in a change in separation efficiency and selectivity. Due to the nature of the feed streams and the relative size of pores and fluid components and high fluxes (several $10^{5}$ of $1 \cdot h^{-1} \cdot \mathrm{m}^{-2}$ ) used in MF, there is a tendency of large particles or colloidal aggregates to be trapped in the pores, followed by cake formation on the surface of the membrane, and the creation of a new membrane layer. This layer (if steps are not taken to prevent its formation), starts to govern the overall filtration characteristics and is independent in its rejection properties of the initial pore size of the membrane. One of the best ways to prevent this phenomena from occurring is to increase the shear rate on the membrane surface, in order to sweep away the accumulating particulates retained by the membrane (Maubois et al, 1987), and to periodically backflush (Merin et al, 1983a; Galaj et al, 1984). The former is well achieved by the implementation of special turbulent promoters on the membrane surface and by varying the crossflow velocity of the feed stream (Van Der Horst and Hanemaaijer, 1989). This increase in flow velocity is associated with changes of several operating parameters, which contradict one another in its contribution to extended MF operation. Crossflow velocity is directly proportional to elevated flux owing to increased pressure drop along the module (PD) and transmembrane pressure drop (TP). These undesirable changes in performance were overcome by the introduction of MF modules which maintain constant TP drop at high flow velocities (Holm et al, 1986; Malmberg and Holm, 1988).

\section{CROSSFLOW MICROFILTRATION MEMBRANES}

At present, microfilters are commercially available from several manufacturers in different configurations. Some of the more suitable configurations for microfiltration uses, which can handle viscous liquids, are tubular systems and pleated tangential 
crossflow cartridges, which achieve high crossflow velocities on the membrane surface. Flat sheet membranes of the appropriate pore size could also be.used in any existing plate-and-frame or flat-sheet tangential flow membrane units, with the limits of the laminar flow of these units. Microfiltration is still in its introductory stage. Figures for 1988 indicate over $6500 \mathrm{~m}^{2}$ installed membrane area for beverage filtration and over $1250 \mathrm{~m}^{2}$ for gelatin and dairy applications (fig 1; Van Der Horst and Hanemaaijer, 1989). In order to obtain an acceptable MF performance, it is necessary to study and assess the right membrane characteristics, with respect to sharp pore diameters, process variables and special treatments of the feed streams (Merin and Daufin, 1989). The state of

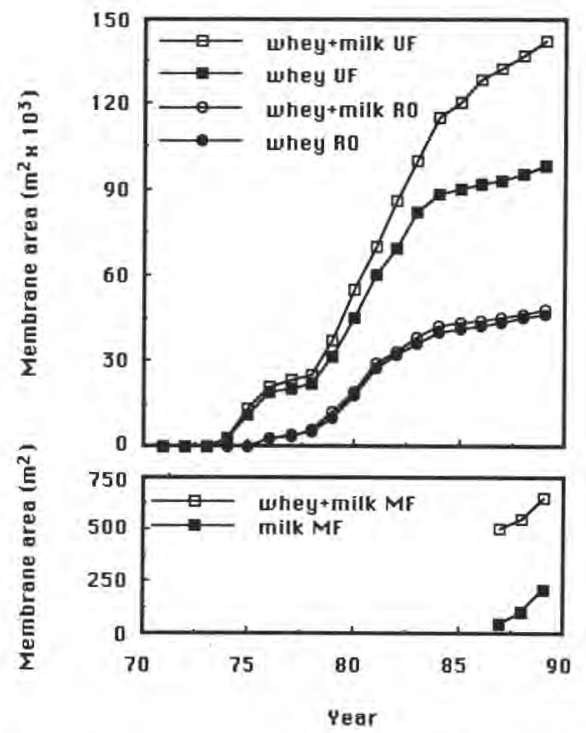

Fig 1. Total membrane area for RO, UF and CFMF in the dairy industry 1971-1988. (Van Der Horst and Hanemaaijer, 1989; reproduced with permission).

Aire totale de membranes pour l'osmose inverse (RO), I'ultrafiltration (UF) et la microfiltration tangentielle (MF) dans l'industrie laitière. crossflow filtration has been reviewed by Henry (1972) and CFMF in the food industry by Gekas et al (1985) and Van Der Horst and Hanemaaijer (1989). The use and application of inorganic MF membranes in the food industry were recently reviewed by Merin and Daufin (1989).

\section{MICROFILTRATION APPLICATIONS IN THE DAIRY INDUSTRY}

CFMF is an adequate tool for use in the dairy industry for several purposes. It can achieve separation of bacteria from whole or defatted milk, fat from whole milk and casein micelles from soluble proteins. Whey can be defatted and clarified for subsequent production of high quality whey protein concentrates (WPC). After the introduction of CFMF modules in the seventies, their application to various streams were reported (Henry and Allred, 1972; Griffith et al, 1979; Tanny et al, 1980).

\section{Microfiltration of whey}

Whey UF performances during WPC production are altered by membrane fouling (Taddei, 1986). Removal of the major components responsible for such a phenomenon, using pre-treatment of the feed streams, has been suggested to overcome fouling. It was reported that calcium and mineral salts could precipitate in the membrane pores (Maubois, 1980), or form saltbridges between the membrane and the proteins (Cheryan and Merin, 1981). Daufin et al (1989) have brought experimental evidence through IR and XPS spectroscopies of these 2 fouling mechanisms of UF membranes, thus, supporting these previous findings. Consequently, calcium removal by calcium sequestrates, ion exchange resins, dialysis and adjustment 
of $\mathrm{pH}$ followed by centrifugation (Lee and Merson, 1976b; Merin and Cheryan, 1980; Ennis et al, 1981; Kuo and Cheryan, 1983; Patoka and Jelen, 1986; Taddei, 1986) is one of the more successful suggestions to improve UF fluxes.

The above-mentioned pre-treatments left the whey rich in soluble particles, which, during UF, formed a limiting layer on the membrane surface. Evidence seemed to indicate that the removal of lipids from whey had a beneficial effect on UF membrane flux (Lee and Merson, 1976a; Muller and Harper, 1979; Tanny et al, 1982; Merin et al, 1983b; Hanemaaijer, 1985; Merin, 1986; Van Der Horst and Hanemaaijer, 1989). In commercial UF of cheese whey, the fat is almost always removed before processing, but noncentrifugable phospholipoprotein (PLP) content after concentration of the defatted stream is high enough to cause problems. Lipids have been reported to have an adverse effect on the properties of the final whey protein concentrate (WPC), such as a decrease in foaming and susceptibility to peroxidation (Richert et al, 1974; De Boer et al, 1977).

The numerous works that have pointed out $\mathrm{Ca}$ ions, fat residues, casein fines and bacteria as obstacles to improve UF flux and quality of the concentrated proteins produced, highlighted the potential of a microporous tangential flow filter to overcome these problems. These goals were achieved by generating a feed stream devoid of the above-mentioned species, and the introduction of inorganic membranes gave it further impetus.

The first reports on the use of CFMF cartridge in the dairy industry dealt with pre-treatment of whey for defatting and casein fines removal from sweet whey (Tanny et al, 1982), and for cheese brine clarification (Merin et al, 1983a). Protein rejection from whey in CFMF, using 1.2 $\mu \mathrm{m}$ membranes was reported to be $5-6 \%$. Globular fat was totally removed from the permeate stream while bacteria was reduced by $2-3$ orders of magnitude (Merin et al, 1983b). It was also observed that microfiltered whey had $25-30 \%$ higher UF fluxes compared to centrifuge-clarified whey. Inorganic carbon- $\mathrm{ZrO}_{2} \mathrm{MF}$ membranes along with some polymeric membranes rejected about $15-20 \%$ of the proteins and lowered bacteria counts by 5 orders of magnitude (Piot et al, 1984).

A comparison of some MF modules available for pre-treatment of whey for WPC manufacture was reported by Hanemaaijer (1985). He concluded that all the modules were not removing fat to a desired level, and suggested a combined MF/ UF process for WPC manufacture after initial concentration of the feed whey by RO or evaporation (Hanemaaijer, 1985). Recently, Van Der Horst and Hanemaaijer (1989) listed the properties of different CFMF membranes tested at NIZO for the processing of fat-free concentrated whey. In batch concentration of whey, with a total solid content of $25 \%$ up to a volume reduction of $80 \%$, they reported possible fat reduction factor of 20-60, using CFMF. Owing to membrane fouling, fluxes were low $\left(28-53 \mathrm{l} \cdot \mathrm{h}^{-1} \cdot \mathrm{m}^{-2}\right)$ depending on membrane type.

Residual fat removal from whey is based on the tendency of phospholipoproteins (PLP) to aggregate under ionic calcium binding, $\mathrm{pH}$ change and heat treatment (Fauquant et al, 1985). It was further developed to an industrial applicable process which uses CFMF to separate the aggregated mass from the whey, resulting in a crystal clear filtrate that can be further concentrated via UF to produce high quality, fat-free WPC (Maubois et al, 1987). Permeation rate and rejection values for $\beta$ lactoglobulin and $\alpha$-lactalbumin during that MF step were strongly dependent on tan- 
gential flow velocity and also on the type of pump used. It was shown that tangential flow rate up to $6 \mathrm{~m} \cdot \mathrm{s}^{-1}$, using whey and milk, still results in better permeation fluxes and protein transmission to the permeate. Centrifugal pumps with a closed turbine, used by the authors, were proven to operate well and could compromise for the high cost of volumetric pumps (fig 2). After the thermocalcic aggregation of the PLP, MF

\section{MICROFILTRATION}
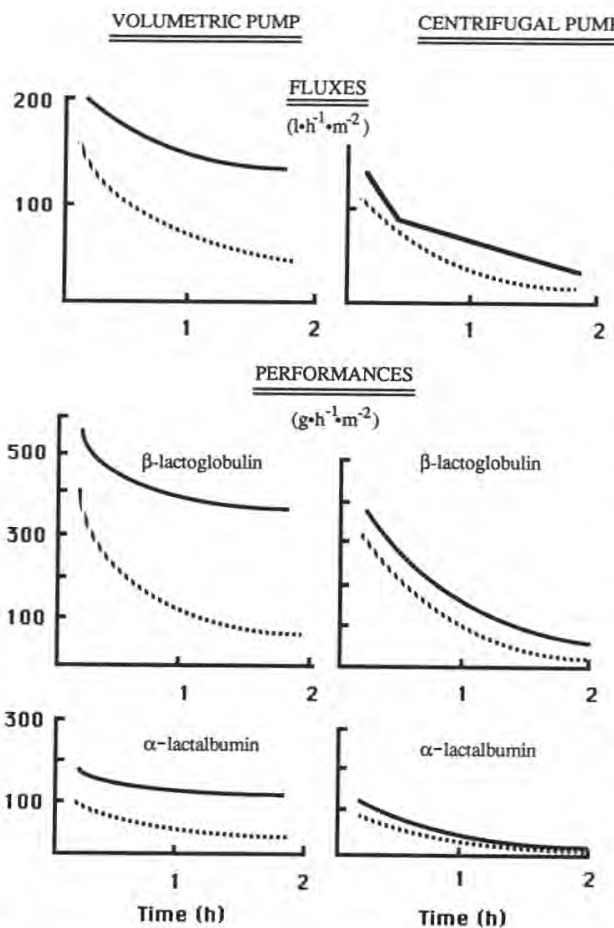

Fig 2. Performance of centrifugal pump vs volumetric pump for microfiltration. M14 Carbosep membrane; Protein content: $6.1 \mathrm{~g} \cdot \mathrm{kg}^{-1}$; Transmembrane pressure: 0.9 bar; Flow rate $\left(\mathrm{m} \cdot \mathrm{s}^{-1}\right)$ : --- 6.0; - . - 4.5 (Maubois et al, 1987; reproduced with permission).

Performances comparées des pompes centrifuges et volumétriques pour la microfiltration de lactosérum. fluxes are about $100 \%$ higher than for the treated whey and UF fluxes increase by 1.8 (Maubois et al, 1987). In order to retain most of the whey proteins during the subsequent UF process, after this MF treatment, a decrease of membrane pore size must be made. The resultant MF permeate after the above process opens up a new variety of uses of this stream, from hydrolysis to peptides and pharmaceutical and medical uses to fractionation of the individual whey proteins. It should be noted that MF of whey utilizing $\mathrm{M}^{14}$ carbon- $\mathrm{ZrO}_{2}$ membranes $(0.14 \mu \mathrm{m}$ pore diameter) is an industrial process today, but there are some drawbacks among which are low fluxes $\left(\leq 60 \mathrm{l} \cdot \mathrm{h}^{-1} \cdot \mathrm{m}^{-2}\right)$, limited operating time $(\leq 10 \mathrm{~h}$ ) due to fouling problems and insufficient transmission of the whey proteins to the permeate.

\section{Microfiltration of milk}

Already in 1975 the Alfa-Laval Company registered a patent for the defatting of milk with polymeric membranes (Glimenius et al, 1975, 1979). These registrations covered: slow flow velocities $\left(<0.5 \mathrm{~m} \cdot \mathrm{s}^{-1}\right)$, $0.2-10 \mu \mathrm{m}$ pore diameter and higher than $0.2 \mathrm{~kg}^{\circ} \mathrm{cm}^{-2}$ pressure drop.

The introduction of inorganic microfilters with pore sizes of $0.1-2 \mu \mathrm{m}$ and high fluxes made it possible to take advantage of this technique for the elimination of bacteria and fat from milk. The relative diameters of some milk constituents are given in table I (Muir and Banks, 1985).

It appears that with skimmed milk, it is possible to separate bacteria from the milk components, whereas, with whole milk, most of the fat is removed with the bacteria. The first pilot studies on MF of whole milk were reported in 1987 (Piot et al, 1987). It was shown that the MF process using an inorganic alumina membrane of 
Table I. Relative diameters of milk constituents. Diamètres relatifs de quelques constituants du lait.

\begin{tabular}{lc}
\hline Component & Size $(\mathrm{nm})$ \\
\hline Water & \\
Cl- Ca++ & 0.3 \\
Lactose & 0.4 \\
Whey proteins & 0.8 \\
Casein micelles & $3-5$ \\
Fat globules & $32-300$ \\
Bacteria & $100-2000$ \\
& $>200$ \\
\hline
\end{tabular}

$4 \mathrm{~mm} \mathrm{ID} \mathrm{and} 1.8 \mu \mathrm{m}$ pore size could skim $98 \%$ of the fat and reduce bacterial counts by 2 orders of magnitude, with no apparent rejection of proteins. It was postulated by several investigators that MF operation needs high crossflow velocities in order to enhance flux. The main problem of operating at such high flow velocities is increased TP and PD along the filter module, especially when operating on a tubular

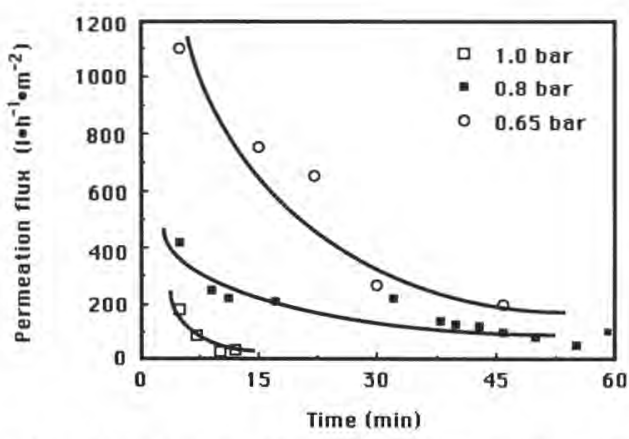

Fig 3. Influence of average transmembrane pressure on fluxes of microfiltration in time. Membralox membrane $(1.8 \mu \mathrm{m})$; whole milk, $50^{\circ} \mathrm{C}$; $5.2 \mathrm{~m} \cdot \mathrm{s}^{-1}$ (Piot et al, 1987; reproduced with permission).

Influence de la pression transmembranaire moyenne sur l'évolution des flux de microfiltration au cours du temps. design. The increase in PD leads to a higher TP, especially at the inlet of the tube, which could cause lower permeation fluxes as was shown by Piot et al (1987) for pressure drop range of $0.65-1.0$ bar (fig 3 ). During concentration of the liquid feed stream, $P D\left(P_{\text {in }}-P_{\text {out }}\right)$ increases. Transmembrane pressure difference at the entrance of the filter is high, it decreases to 0 towards the end of the filter or can even be negative. This means that the average flux measured outside is a mixture between high flux at the entrance and very small flux at the end of the filter. Where there is a high pressure difference fouling will be severe, resulting in blocked pores. There will be an active "fouling" zone that will move from the entrance towards the end of the filter. When this active zone reaches the end of the filter, the whole filter will be blocked and the operation will have to be stopped to clean the filter. A development, patented by Alfa-Laval to overcome high TP drop along tubular modules consists of achieving a uniform transmembrane pressure difference throughout its whole length. This is achieved by circulating the permeate co-current to the feed in such a way, that it builds a pressure profile parallel to it, thus, creating a constant transmembrane difference (Malmberg and Holm, 1988; Plett, 1989) (fig 4).

Semi-industrial trials were carried out, using alumina membranes of $1.4 \mu \mathrm{m}$ pore size, with co-current circulation of permeate. The units were operated at constant fluxes of up to $700 \mathrm{l} \cdot \mathrm{h}^{-1} \cdot \mathrm{m}^{-2}$, for over $6 \mathrm{~h}$ with only 0.1 bar increase in TP for a VCR 10 (Malmberg and Holm, 1988). It was shown that $99.7 \%$ of the bacteria could be removed from skimmed milk with fluxes of over $6401 \cdot \mathrm{h}^{-1} \cdot \mathrm{m}^{-2}$ (Malmberg and Holm, 1988). Removal of Clostridia spores using MF, was 10 times better compared to bactofugation, regardless of initial counts (Piot et al, 1987). Using Bacillus 


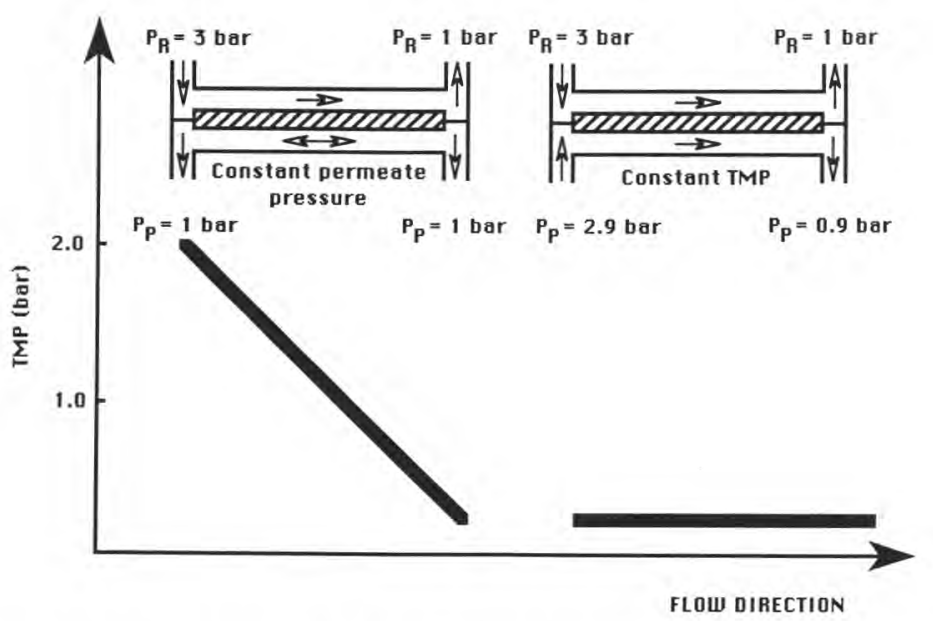

Fig 4. Constant filtrate pressure system and constant transmembrane pressure (TMP) system. (Malmberg and Holm, 1988; reproduced with permission).

Systèmes à pression constante de perméat et à pression transmembranaire constante (TMP).

cereus, as an indicator organism for efficient pasteurization, 10 times fewer counts were found in milk pasteurized after MF (Vincens and Tabard, 1988; Plett, 1989). For VCR 20, the increase of 0.25 bar in TP was needed to maintain a constant flux of $6301 \cdot \mathrm{h}^{-1} \cdot \mathrm{m}^{-2}$ for $5 \mathrm{~h}$ (Plett, 1989). It is claimed that this technique has been improved and can successfully remove bacteria from cheese-milk and fat from whey (Plett, 1989). Nevertheless, Van Der Horst and Hanemaaijer (1989), claimed that a controlled flow arrangement of the permeate to obtain constant and low TP is not principally necessary to achieve good results. They reported that fluxes of 500-700 $\mathrm{kg} \cdot \mathrm{h}^{-1} \cdot \mathrm{m}^{-2}$ are obtained at a whey protein and casein transmission between 97 and $100 \%$ and bacteria retention of $99 \%$, for MF of skimmed milk using a ceramic membrane system with adjusted, carefully controlled start-up procedure.

\section{Phosphocaseinate separation}

Carbon- $\mathrm{ZrO}_{2}$ membranes of $0.2 \mu \mathrm{m}$ pore size were applied to the MF of skimmed milk (Fauquant et al, 1988). Skimmed milk was pasteurized at $72{ }^{\circ} \mathrm{C}$ for $15 \mathrm{~s}$ and microfiltered at low transmembrane pressure and $6 \mathrm{~m} \cdot \mathrm{s}^{-1}$ tangential flow rate. The resulting permeate is an "ideal" whey without fat, bacteria, rennet and glycomacropeptide (Maubois, 1988). The substance contained the native phosphocaseinate which could be further purified by diafiltration.

\section{SOME COMMENTS ON MF SEPARATION SELECTIVITY AND FLUX ENHANCEMENT}

The major "problem" of MF, unlike UF, is that we are predominantly interested in the 
permeate stream, which is usually composed of particles, colloids and small molecular weight solutes, and not in total or maximal molecular size rejected species. This so-called "interest" leads to many problems associated with MF separation, permeation, selectivity etc, and thus needs further elaboration.

\section{Separation, pore size and pore size distribution}

MF membranes do not merely operate on molecular weight rejection as do UF and RO membranes. Since MF deals with particles and colloid, even when eliminating the limiting fouling phenomena (thus operating with an ideal membrane), separation will still be governed by other factors rather than pure pore size. Most molecules greater than the pore size, will be rejected as in UF, but transmission of species smaller than the pores will be attributed to various factors. These factors include particle stearic configuration and charges, hydrodynamic friction with other species and membrane surfaces, surface-particle, pore wall-particle and particle-particle interactions and pressure drop across the membrane and module. Since, in the dairy industry we are not dealing with a uniformsize ideal feed stream, the abovementioned factors are tremendously enhanced with particles being of different shape and size. Charges play a major role in respect to interactions between particles, colloid and metal ions and thus, any $\mathrm{pH}$, temperature, pressure changes etc will result in a change of membrane performance with time.

\section{Membrane fouling and its prevention}

As mentioned before, MF is susceptible to fouling which is characterized by 3 main points:

- adsorption and adhesion of particles and solute to surfaces;

- concentration polarization and cake formation;

- pore blocking.

Adsorption and adhesion are related to interactions between the membrane and the feed components due to forces such as: hydrophobicity and hydrophilicity, dipole, hydrogen and chemical bonds, Van der Waals and electrical forces etc. Varying the membrane material could eliminate some of it, but that is not always found experimentally.

Concentration polarization and cake formation must be diminished by adopting adequate operating parameters, such as high shear forces due to flow velocity and careful module design, in order to enhance mass transfer coefficient.

Pore blocking is of major importance, especially owing to the close size of the rejected and transmitted species. The pores must bare minimum attraction to the permeated species, which, after passing the pores must be freely removed through the support layer. Membrane "perfect" asymmetry and open structure of the support layer combined with a preferably active removal of the permeated particles, at constant TP, rather than a discharge to atmospheric pressure (as is the case in the Bactocatch process) may enhance MF performance). 


\section{Cleaning of MF membranes}

Cleaning of MF membranes is performed in the same way as for UF ones, and the only difference is the applied pressure. A sequential use of water, enzyme and acid was proposed by Merin et al (1983a) for flux restoration after cheese brine filtration. They noted that a base wash resulted in a blocked membrane, which was only recovered by a further acidic wash. A similar sequence was used by these authors for whey MF. In all cases, a final chlorine rinse at concentration of $150 \mathrm{mg}^{-1}$ was used as a sanitizer. An example of alkaline-acid sequence is described by Plett (1989), for cleaning of $0.2 \mu \mathrm{m}$ alumina membranes used for bacteria removal from skimmed milk. Inorganic MF membrane cleaning is performed in the same way as UF inorganic ones. It is constituted of an acid, base and sometimes enzyme wash, followed by a water rinse. Inorganic membranes can withstand high chlorine concentration (Merin and Daufin, 1989). A cleaning cycle with acid and base including $1000 \mathrm{mg}^{\circ} \mathrm{l}^{-1}$ active chlorine was also effective in cleaning UF inorganic membranes after whey and milk filtration (Kerhervé et al, 1989). Water purification, for any use with organic and inorganic membranes, such as diafiltration, rinsing, cleaning, and PWF measurements is necessary. Special characteristics of the polymers, as well as the oxide metals (ie pl), leads to interactions between the membrane surface and ionic salts (Merin et al, 1983a; Duclert and Rumeau, 1989). Most colloid and minerals should be removed from water which will be in contact with the membranes.

\section{CONCLUSION}

In order to assist the implementation of MF in the dairy industry, a few points must be fulfilled. Fouling must be limited by thinning of the concentration polarization or cake layer by high tangential flow rates. It will necessitate the manufacture of systems to overcome the high pressure drops. Adsorption of feed components to the membrane should be kept to a minimum by using appropriate membrane materials and/ or special pre-treatements of their surfaces. Adequate selection of membrane pore size and pore size distribution to fit particle size and the use of pumps which do not alter particle size due to shear forces, could result in less fouling and better selectivity.

\section{ACKNOWLEDGMENTS}

The authors gratefully acknowledge the valuable suggestions of JL Maubois, G Brulé, M Piot and E Trouvé (LRTL - INRA Rennes).

\section{REFERENCES}

Belfort G (1985) Membrane separation technology, an overview. In: Advanced Biochemical Engineering (Bungay $\mathrm{H}$, Belfort $\mathrm{G}$, eds) John Wiley and Sons Inc, New York, ch 9, 239-297

Bertera R, Steven H, Metcalfe M (1984) Development studies of crossflow microfiltration. Chem Eng 404, 10-14

Cheryan M (1986) Ultrafiltration Handbook. Technomic Publ Inc Lancester, PA, USA

Cheryan M, Merin U (1981) The effect of protein-mineral-membrane interactions on the fouling of ultrafiltration membranes. In: Fundamentals and Applications of Surface Phenomenon Associated with Fouling and Cleaning in Food Processing (Hallstrom B, Lund $D B$, Tragardh C, eds) Lund Univ Press, Sweden, 204-214

Daufin G, Labbé JP, Quemerais A, Michel F, Robert F, Fiaud C (1989) Spectroscopic analysis of fouling layers of inorganic ultrafiltration membranes. In: Fouling and Cleaning in Food Processing (Kessler HG, Lund DB, eds) 207-215 
De Boer R, De Wit JN, Hiddink J (1977) Processing of whey by means of membranes and some applications of whey protein concentrate. J Soc Dairy Technol 30, 112-120

Duclert F, Rumeau M (1989) Microfiltration d'eau sur membranes minérales. Influence des sels et des gaz. Liq Mag 9 (1-2), 33-35

Ennis BM, Johns JEM, O'Connell MT (1981) The effect of the replacement of calcium with sodium on the ultrafiltration of acid whey. NZJ Dairy Sci Technol 16, 69-78

Fauquant J, Maubois JL, Pierre A (1988) Microfiltration du lait sur membrane minérale. Tech Lait Market 1028, 21-23

Fauquant J, Vieco S, Brulé $G$, Maubois JL (1985) Clarification des lactosérums doux par agrégation thermocalcique de la matière grasse résiduelle. Lait 65, 1-20

Galaj S, Wicker A, Dumas JP, Gillot J, Garcera D (1984) Microfiltration tangentielle avec décolmatage sur membranes céramiques. Lait $64,129-140$

Gekas V, Hallstrom B, Tragardh G (1985) Food and dairy applications: the state-of-the-art. Desalination $53,95-127$

Glimenius AR, Jansson GT, Kemi KWH, Sandblom RM (1975) Process for separating liquid milk products. Swedish Patent Application No 380442

Glimenius AR, Jansson GT, Kemi KWH, Sandblom RM (1979) Filtering method for separating skim milk from milk products. US Patent No 4140806

Griffith WL, Tanny GB, Compere AL (1979) Evaluation of tangential filtration methods for the recovery of scleroglucans. Dev Ind Microbiol 20, 743-750

Hanemaaijer $\mathrm{JH}$ (1985) Microfiltration in whey processing. Desalination 53, 143-155

Henry JD Jr (1972) Crossflow filtration. In: Recent Developments in Separation Science (Li NN, ed), CRC Press, Cleveland, $\mathrm{OH}$ II, 205225

Henry JD Jr, Allred R (1972) Concentration of bacterial cells by crossflow filtration. Dev Ind Microbiol 13, 177

Holm S, Malmberg R, Swensson K (1986) Method and plant for producing milk with low bacterial content. Patent PCT WO 86/01687
Kerhervé FL, Rio S, Merin U, Labbé JP, Quemerais A, Michel F, Daufin G (1990) Nettoyage de membranes d'ultrafiltration de lactosérum et de lait. Proc 1st Int Conf Inorganic Membranes, Montpellier, France, 419-423

Kuo KP, Cheryan M (1983) Ultrafiltration of acid whey in a spiral-wound unit: effect of operating parameters on membrane fouling. $J$ Food Sci 48, 1113-1118

Lee DN, Merson RL (1976a) Prefiltration of cottage cheese whey to reduce fouling of ultrafiltration membranes. J Food Sci 41, 403-410

Lee DN, Merson RL (1976b) Chemical treatment of cottage cheese whey to reduce fouling of ultrafiltration membranes. $J$ Food Sci $41,778-786$

Lonsdale HK (1982) The growth of membrane technology. J Membr Sci 10, 81-181

Malmberg M, Holm S (1988) Low bacteria skim milk by microfiltration. North Eur Food Dairy $J$ 54, 75-78

Maubois JL (1980) Ultrafiltration of whey. J SoC Dairy Technol 33, 55-58

Maubois JL (1988) Whey, its biotechnological signification. 8th Int Biotechnol Symp, July 17-22, Paris, France

Maubois JL, Pierre A, Fauquant J, Piot M (1987) Industrial fractionation of main whey proteins. Int Dairy Fed Annu Bull 212, 154-159

Merin U (1986) Bacteriological aspects of microfiltration of cheese whey. J Dairy Sci 69, 326328

Merin U, Cheryan M (1980) Factors affecting the mechanism of flux decline during ultrafiltration of cottage cheese whey. J Food Process Preserv 4, 183-198

Merin U, Daufin G (1989) Separation processes using inorganic membranes in the food industry. Proceedings 1st Int Conf Inorganic Membranes, Montpellier, France, 271-281

Merin U, Gordin S, Tanny GB (1983a) Microfiltration of cheese brine. $J$ Dairy Res 50,503 509

Merin U, Gordin S, Tanny GB (1983b) Microfiltration of sweet cheese whey. NZJ Dairy Sci Technol 18, 153-160

Muir DD, Banks JM (1985) Developments in membrane technology. J Soc Dairy Technol $38,116-119$ 
Muller LL, Harper JJ (1979) Effect on membrane processing of pretreatment of whey. $J$ Agric Food Chem 27, 662-664

Patoka J, Jelen P (1987) Calcium chelation and other pre-treatments for flux improvement in ultrafiltration of cottage cheese whey. J Food Sci 52, 1241-1244

Pettipher GL, Mansell R, MC Kinnon CH, Cousins CM (1980) Rapid membrane filtration. Epifluorescent microscopy technique for direct enumeration of bacteria in raw milk. Appl Environ Microbiol 39, 423-429

Piot M, Maubois JL, Schaegis $P$, Veyre R, Luccioni $A$ (1984) Microfiltration en flux tangentiel des lactosérums de fromagerie. Lait 64, 102-120

Piot P, Vachot JC, Veaux M, Maubois JL, Brinkman GE (1987) Ecrémage et épuration bactérienne du lait entier cru par microfiltration sur membrane en flux tangentiel. Tech Lait Market 1016, 42-46

Plett E (1989) The constant pressure difference method for microfiltration. 3rd Int Conf on Fouling and Cleaning in Food Processing, June 4-7, Prien, FRG

Porter MC (1986) Microfiltration. In: Synthetic Membranes: Science, Engineering and Appli- cations (Bungay PM, Lonsdale HK, De Pinho MN, eds) Reidel Publ Co Dordrecht, The Netherlands, 225-247

Richert SH, Morr CV, Cooney CM (1974) Effect of heat and other factors upon foaming properties of whey protein concentrates. $J$ Food Sci $39,42-48$

Taddei C (1986) Mécanismes influençant le transfert de matière lors de l'ultrafiltration de lactosérum. Thesis, Toulouse Univ, France

Tanny GB (1978) Dynamic membranes in ultrafiltration and reverse osmosis. Sep Purif Methods 7, 183-220

Tanny GB, Hauk D, Merin U (1982) Biotechnical applications of a pleated crossflow microfiltration module. Desalination 41, 299-312

Tanny GB, Mirelman D, Pistole (1980) Improved filtration technique for concentrating and harvesting bacteria. Appl Environ Microbiol 40, 269-273

Van Der Horst HC, Hanemaaijer JH (1989) Cross-flow microfiltration in the food industry: state-of-the-art. Membrane Technology Symposium, Tylosand, Sweden, June 12-14

Vincens D, Tabard J (1988) L'élimination des germes bactériens sur membranes de microfiltration. Tech Lait Market 1033, 62-64 